Andreász Kosztopulosz - Éva Kuruczleki (eds.) (2020): The Challenges of Analyzing Social and Economic Processes in the 21st Century. University of Szeged Faculty of Economics and Business Administration, Szeged, https://doi.org/10.14232/casep21c.18

\title{
Investigation of eating behaviour among primary school children with Dutch Eating Behaviour Questionnaire (DEBQ)
}

\author{
Dalma Pető
}

\begin{abstract}
There are many factors that influence children's eating, and the role of parents is outstanding. During our research, we studied children's eating behaviour and were also interested in parents' attitudes towards their children's eating behaviour. In the course of our investigation, we used a part of the already validated questionnaire, DEBQ. Our sample was made up of primary school children and their parents. A total of 172 children and their parents completed the questionnaire. The results show that parents consider the child's nutritional characteristics differently than the child itself. We found that parents overestimate their children's self-control about delicious food.
\end{abstract}

Keywords: healthy nutrition, DEBQ, eating

\section{Introduction}

The data related to healthcare expenses indicate that households spend increasing amounts of money for that purpose, on medicines, medical appliances and other goods of medical use in particular (KSH 2017). The factors affecting a person's health can be divided into two groups. The uncontrollable risk factors include innate genetic attributes, characteristics gained over the years, gender and age. The factor we can control is lifestyle. Health is determined in the highest proportion by lifestyle (43\%), followed by genetic factors (27\%), environmental effects (19\%) and healthcare $(11 \%)$ (Varga-Hatos-Karner 2008).

Among lifestyle factors, nutrition is crucial from the perspective of our health. Our eating habits develop as early as our childhood, and they influence our later state of health. Malnutrition may affect our whole life and even shorten it. Therefore it is important to pay attention to the evolvement of proper eating habits from children's early age (Huszka-Dernóczy 2015).

Malnutrition can be the source of several illnesses, such as cancer or cardiovascular diseases, especially if it is accompanied by an unhealthy lifestyle. Children malnourished at an early age will be more susceptible to these illnesses in the longer term. Young people from lower income layers, eating food with low nutrient contents, are particularly prone to this. Parents are forced to put cheap and quickly prepared dishes on the table, which often contain high calories and fat. The spread of nutrient-poor fast foods contributes to the increasing rate of obesity starting in childhood, and its treatment is a growing challenge all over the world (Khatoon et al. 2017, Vazquez-Torres 2012). Comparing the current data and the data from two decades ago, it can be seen that the number of obese children has doubled, while the number of obese adolescents has tripled (Vazquez-Torres 2012). The first signs of 
several chronic diseases (such as cardiovascular diseases, diabetes, and obesity) are already detectable in childhood (Black et al. 2017). In addition, psychological illnesses, such as depression also accompany obesity, which means an even worse quality of life for the individual (Vazquez-Torres 2012).

Based on this it can be claimed that it is extremely important to deal with nutrition. It is particularly true from the aspect of children since they are the future's consumers and employees, and therefore their health is a high priority. Young people's nutrition can be affected by several factors, one of them is the influence of parents. In the course of our research, we studied children's eating behaviour with a novel approach. We were interested in finding out whether parents assess their children's nutrition characteristics in the same way as their children, or, in other words, whether they are able to identify the nutrition characteristics their children consider about themselves. To examine this we conducted a questionnaire survey among primary school children and their parents, and the results are presented in the following.

\section{The factors influencing children's eating}

Parents' influence is determining from the perspective of children, they affect longterm eating behaviour as early as infancy. The more a parent prohibits and restricts the child's independent decisions related to eating, the bigger the chance is that the child will start eating unhealthily later on. As soon as they can make an own decision about their diet, they will choose a prohibited alternative, even if they are not hungry (European Food Council 2012). There is a strong connection between the parents' and their children's nutrition attitude, as the children of parents who pay attention to healthy nutrition are more health conscious themselves and they are more interested in the topic (Kiss-Szakály 2016). In their research, Kiss and Szakály (2016) found that the mother's role is much stronger, they consider her as the person supporting a healthy lifestyle, while the father's role is much weaker, yet positive. Despite this, only $1 / 3$ of children believe that they get reliable answers to their questions regarding lifestyle and nutrition from their parents. For them health visitors and doctors represent a credible source of information. Besides, the internet is the third most important information channel for the young (Kiss-Szakály 2016). The more say parents have in the eating habits of their children, the more balanced diet the children have (Böröndi et al. 2010).

It is an important question how we can influence children's eating in the early stage of their development. As in this age the family stands in the centre of children's life, convincing the parents is an inevitable step for the purpose of educating to sustainable and healthy nutrition. According to related research, the nutrition programmes focusing on the family and providing information for the parents about nutrition have proved to be much more successful than the programmes based on schools. In the case of the former, fat intake significantly decreased, and the consumption of vegetable and fruit increased, while in the case of the latter there was only a moderate increase in vegetable and fruit consumption (Black et al. 2017). It is also important to note the effect of the media, since it can easily influence the food 
choice behaviour even at this age. Children spend more and more time in front of the screen, whether it is a TV or computer. It entails encountering more and more advertisements promoting fast food (Vazquez-Torres 2012). The techniques advertisers use have an influence on children's preferences related to food and encourage them to consume fast food (Boyland-Whale 2015). Children's brand preferences develop already at this early age, which can affect their life later on (Kásler 2017).

\section{Studying eating behaviour}

Eating behaviour is considered to be the most important factor regarding the treatment and prevention of obesity and related illnesses (Danielsen et al. 2013). The eating behaviour studies mostly take three theories as a basis: psychosomatic theory, external theory and the theory of restraint. According to the psychosomatic theory, those who eat triggered by emotions (fear, anger, anxiety) do not recognise this stimulus, and therefore they take too many calories in their body (Kaplan-Kaplan 1957). External theory has a similar position, claiming that the external environment determines eating behaviour and the vision and smell of food generate an overly strong reaction in overweight people (Schachter-Rodin 1974). The theory of restraint is also related to eating behaviour, saying that during diet the individual consciously restrains food consumption to reduce or maintain weight, which leads to metabolic processes slowing down and reducing the feeling of hunger. However, as soon as self-control decreases (for example, as a result of alcohol or negative emotions), cognitive restraint decreases and eating behaviour turns into the opposite direction, leading to excessive food intake. Furthermore, as a result of restrained eating, the individual may lose control over the feeling of hunger and the feeling of satiety, which leads to eating based on emotional or external effects (Herman-Polivy 1975).

A lot of research is concerned with eating behaviour and attitudes, several measuring methods have been developed for their investigation (based on the theories above). Garner and Garfinkel's (1979) Eating Attitude Test (EAT) is mainly used to study eating disorders. Herman and Polivy's (1980) Restraint Scale measures how consciously an individual restrains food intake in order to restrain their weight. This questionnaire provided the basis for the Three Factor Eating Questionnaire (TFEQ) (Stunkard-Messick 1985) and the Dutch Eating Behavior Questionnaire (DEBQ) (Van Strien et al. 1986). Both analyse three eating behaviours: the TFEQ distinguishes between uncontrolled eating, cognitive restraint and emotional eating, and the DEBQ differentiates restrained eating, emotional eating and external eating. The main difference between DEBQ and TFEQ is the external eating (DEBQ) and the uncontrolled eating (TFEQ) scale. In case of uncontrolled eating, the individual loses control over her eating behavior for some reason, he/she is disturbed by something, so eats more. External eating is a special form of uncontrolled eating behavior associated with loss of control which occurs from a response to food-related (external - smell and internal - hunger) signals (Heaven et al. 2001). In our case, the external eating scale - based on Schachter and Rodin's (1974) external theory - is a better choice for our research purpose, because of the young target group. 
In our present research we used the Dutch Eating Behavior Questionnaire (DEBQ). The questionnaire intended to measure eating behaviour was developed by van Strien and co. in 1986. The questionnaire originally including 46 items was later reduced to 33 questions, which since then has been validated in many countries (including Brazil, China, Spain and France) (Moreira et al. 2017, Wu et al. 2017, Cebolla et al. 2014, Bailly et al. 2012).

The questionnaire examines eating behaviour with the help of three subscales. The external eating scale studies the consumption affected by external stimuli related to food regardless of the individual's feeling of hunger. The restrained eating scale measures whether the individual restrains food consumption intentionally in order to reduce weight or prevent overweight. The third, emotional eating scale analyses the effect of emotions (such as anger, tension and anxiety) on nutrition (Van Strien et al. 1986).

\section{Methodology}

Our paper-based questionnaire was given to the pupils in $3-6^{\text {th }}$ years of a primary school in Szeged, as well as to their parents with the help of the school director. Altogether we asked 172 children and 172 parent. Responding to the questionnaire was not anonymous, each pupil and parent had an identification number. For this reason, we asked the parents to fill in a consent form before responding, so only those who agreed for them and their children to fill in the questionnaire were included in the sample. The questionnaires of the related parents and pupils had the same code so they could be matched. It allowed us to compare the children's and the parents' opinion with each other. The data collection took place in the fall of 2018. The research was carried out on the basis of the medical ethics permit 62/2018-SZTE.

In the course of our investigation we used a part of two already validated questionnaire, the Dutch Eating Behavior Questionnaire (DEBQ) (van Strien et al. 1986), and a version of DEBQ-C (van Strien-Oosterveld 2008) developed for the study of children. A total of nine statements from the original and child-adapted versions were used for both the child and parent questionnaires. The adapted questionnaire is specifically designed to assess children's eating habits as it measures the same three eating styles with shorter, i.e., fewer questions than the original DEBQ scales. For each of the three factors of the model (emotional eating, restrained eating, eating for external influences), three 1-5 Likert scale statements were selected based on our research team's previous investigations with the DEBQ. According to that these 3-3 statements described best the three factors (Lipták-Huszár-Buzás 2018). On the scale, respondents had to indicate how much they agreed with the statement. In the case of children, the statements were formulated considering themselves, while in the case of parents the questions concerned the children (Table 1). 
Table 1 The DEBQ statements included in the child and parent questionnaire

\begin{tabular}{|c|c|}
\hline Statements included in the child questionnaire & $\begin{array}{l}\text { Statements included in the parent } \\
\text { questionnaire }\end{array}$ \\
\hline 1 When I'm sad, I have a desire to eat. & 1 When my child is sad, he/she has a desire to eat. \\
\hline 2 When I feel lonely, I have a desire to eat. & 2 It is hard for my child to resist delicious dishes. \\
\hline $\begin{array}{l}3 \text { If I eat a lot, I pay attention to eat less on the } \\
\text { following days. }\end{array}$ & 3 My child pays attention to eat low-fat food. \\
\hline $\begin{array}{l}4 \text { I intentionally eat less in order not to gain } \\
\text { weight. }\end{array}$ & $\begin{array}{l}4 \text { When my child feels lonely, he/she has a desire } \\
\text { to eat. }\end{array}$ \\
\hline $\begin{array}{l}5 \text { I often desire food when I see other people } \\
\text { eating. }\end{array}$ & $\begin{array}{l}5 \text { My child often desires food when he/she sees } \\
\text { other people eating. }\end{array}$ \\
\hline 6 It is hard for me to resist delicious dishes. & $\begin{array}{l}6 \text { When bad things happen to my child, he/she has } \\
\text { a desire to eat. }\end{array}$ \\
\hline 7 I pay attention to eat low-fat food. & $\begin{array}{l}7 \text { When my child sees good-smelling or delicious } \\
\text { food, he/she gladly has a taste. }\end{array}$ \\
\hline $\begin{array}{l}8 \text { When bad things happen to me, I have a desire } \\
\text { to eat. }\end{array}$ & $\begin{array}{l}8 \text { When my child eats a lot, he/she pays attention } \\
\text { to eat less on the following days. }\end{array}$ \\
\hline $\begin{array}{l}9 \text { When I see good-smelling or delicious food, I } \\
\text { would gladly have a taste. }\end{array}$ & $\begin{array}{l}9 \text { My child intentionally eats less in order not to } \\
\text { gain weight. }\end{array}$ \\
\hline
\end{tabular}

Source: own construct based on DEBQ

Based on the original model, in the case of the child questionnaire the $1^{\text {st }}, 2^{\text {nd }}$ and $8^{\text {th }}$ statements belong to emotional eating, the $3^{\text {rd }}, 4^{\text {th }}$ and $7^{\text {th }}$ statements to restrained eating, while the $5^{\text {th }}, 6^{\text {th }}$ and $9^{\text {th }}$ statements to external eating factors. In the case of the parent questionnaire, $1^{\text {st }}, 4^{\text {th }}$ and $6^{\text {th }}$ original variables belong to emotional eating factors, the $3^{\text {rd }}, 8^{\text {th }}$ and $9^{\text {th }}$ original variables to restrained eating factors, while the $2^{\text {nd }}, 5^{\text {th }}$ and $7^{\text {th }}$ original variables to external eating factors.

\section{Results}

In the course of our research, we used IBM SPSS statistics software and the Microsoft Excel programs to analyse data and test the hypotheses. During the analysis, besides descriptive statistical analysis, we tested principal component analysis, scaling, median tests and correlation coefficients. In our study we call the artificial variables created as a result of the principal component analysis factors for the sake of simplification and easier understanding. In the course of analysis, we were interested to find out whether the original DEBQ model factors can be identified for the parents and children included in the sample, i.e. whether emotional eating, restrained eating and external eating factors can be replicated from the original variables. We also examined if there is a significant difference between the parents and their children in the case of each factor, and if yes, in what ways the responses differ. Thus, our hypotheses we tested were the following: 
- H1.: The 3 factors of the DEBQ model (emotional eating; external eating; restrained eating) can be identified on the sample.

○ H1a.: The 3 factors of the DEBQ model (emotional eating; external eating; restrained eating) can be identified on the child sample.

○ H1b.: The 3 factors of the DEBQ model (emotional eating; external eating; restrained eating) can be identified on the parent sample.

- H2.: There are differences between the children's and parents' responses.

- H2a.: There is a difference between the children's and parents' responses in the case of emotional eating factors.

○ H2b.: There is a difference between the children's and parents' responses in the case of external eating factors.

○ H2c.: There is a difference between the children's and parents' responses in the case of restrained eating factors.

\subsection{The characteristics of the sample}

The questionnaire was filled in by 172 children and related parents in total. 46.8 per cent of the children were boys, while 53.2 per cent were girls. 26.9 per cent of them were in third, 35.1 percent in fourth and 28.1 per cent in sixth year. The proportion of fifth-year pupils was lower compared to the other years, they comprised only 9.9 per cent of the sample. The majority of the children (86\%) were town-dwellers, while 12.3 per cent lived in a village, and only 3 persons in a cottage. 83.1 per cent of the children lived in a household of 3-4-5 people. 8.2 per cent of them lived in a household of two, while the remaining 8.7 per cent lived in a household of more than 5 people. 91.1 per cent of the parents included in the sample were mothers, 0.6 per cent were foster mothers, while the fathers were represented in the sample in a proportion of 8.2 per cent. 82 per cent lived in partnership $(10 \%)$ or marriage. The remaining 18 per cent include single $(4.7 \%)$, divorced $(11 \%)$ or married parents but living separately from their spouse $(1.2 \%)$, and 1 parent of the sample was a widow.

\subsection{The results of hypothesis analysis}

Regarding the first hypothesis we tested whether the DEBQ factors can be identified in the sample in the case of both children and parents. For its examination we carried out a primary component analysis. In both cases we applied the same settings (Varimax rotation procedure). Table 2 summarizes the results of the principal component analysis run on the child and adult samples respectively. The KMO (Kaiser-Meyer-Olkin) index, indicating if it is sensible to search for background structure between variables, takes a value below 0.7 in the case of both the child (0.685) and the adult (0.644) sample. 
Table 2 The results of the principal component analysis on the child and adult samples

\begin{tabular}{lcc}
\hline & Child & Adult \\
\hline Value of KMO index & 0.685 & 0.644 \\
Sig. value of Bartlett test & $<0.05$ & $<0.05$ \\
Cumulative variance ratio & 64.338 & 65.688 \\
Number of created factors (pc) & 3 & 3 \\
\hline
\end{tabular}

Source: analysis based on own data collection

In this case it is practical to examine the Bartlett test, and look at the correlations in the matrix of the artificial variables and the original variables. The significance value of the Bartlett test was below 0.05 in both cases, which suggests a correlation between the variables. It justifies that it is practical to examine the results of the principal component analysis further. Based on the Kaiser-criterion (eigenvalue>1) the analysis created 3 artificial variables in both cases from the original 9 variables respectively. Furthermore, the cumulative variance ratio, meaning the level of information content preservation, was above the threshold of marketing research $(60 \%)$ in both cases, thus we only had to examine whether our variables condensed in the factors correspond with the original DEBQ model. We found that both samples corresponded, thus we could identify the three factors of the original DEBQ model.

Based on this, the first hypothesis saying that the factors of the original DEBQ model can be identified on the samples has been verified in the case of both the parent and the child sample, thus we accepted it overall for $\mathrm{H} 1$.

Regarding our second hypothesis, we wanted to test whether there is a difference between child and adult responses by factor studying the created artificial variables. In order to examine this, first we conducted scaling with the help of minimum-maximum method for making our values comparable. We designed it in a way that all our data took a numeric value between 1 and 5, similarly to the original variables. Thus, the lowest of the original factors took a value of 1 and the highest took a value of 5, and the intermediate values were transformed into a (not necessarily a whole) numeric value between the two numbers. It led to obtaining comparable variables. We compared the values of children and adults by factor with a two-sample independent median test, and we also analysed the correlation coefficients. The results of our analysis are summarised by Table 3. Before carrying out the median tests, however, we looked at the distribution of differences between the values of related parent and child factors for all three factors by individual. We considered it important to study the proportion of outliers, where the parent and child responses largely differ, since a high proportion may cause bias in the result of the median test. Fortunately, we received a result showing that in the case of all three pairs of factors more than $80 \%$ of the child and parent responses differ with a maximum of 1.5 (for a scale of 1 5 ). The proportion of respondents differing with a maximum of 1.5 for emotional eating factors was $88.5 \%$, for external eating factors $82.1 \%$, and for restrained eating 
factors $84.6 \%$, which results imply that the proportion of outliers was minimal. As in all three cases the proportion of "well behaving" responses was above $80 \%$, a median test can be applied, the results are not biased.

Table 3 The results of the median test and correlation coefficients for the analysis of child and adult factors

\begin{tabular}{lccccc}
\hline Name of factor & $\begin{array}{c}\text { child } \\
\text { median }\end{array}$ & $\begin{array}{c}\text { parent } \\
\text { median }\end{array}$ & $\begin{array}{c}\text { median } \\
\text { test t } \\
\text { value }\end{array}$ & $\begin{array}{c}\text { median } \\
\text { test sig. } \\
\text { value }\end{array}$ & $\begin{array}{c}\text { correlation } \\
\text { coefficient }\end{array}$ \\
\hline Emotional eating & 1.47 & 1.74 & -3.29 & 0.001 & $0.298^{* *}$ \\
External eating & 3.32 & 2.87 & 4.55 & $<0.001$ & $0.384 * *$ \\
Restrained eating & 2.20 & 2.52 & -3.01 & 0.003 & $0.362 * *$ \\
\hline
\end{tabular}

Source: analysis based on own data collection

The results indicate that there was a significant difference between the parents' and children's responses in the case of each factor, thus we accept the $\mathrm{H} 2$ hypothesis, with all its sub-hypotheses. The correlation is significant and positive in each case, showing a weak connection between related factors. In the case of emotional eating and restrained eating, the parents overall agreed more with the statements than their children, at the same time, the children gave higher points to the external effects compared to their parents. It means that the parents are more likely to think that their children pay attention not to eat fatty food or not to eat too much, furthermore, they believe their children are more prone to eat when in a bad mood, while they are less likely to think that their children cannot resist an appetising and good-smelling dish. On the other hand, it should be noted that the children and parents gave higher points to the same factors. Both groups agreed that the external effects have the greatest influence on children's consumption, restrained eating has a smaller role in children's nutrition and both the parents and children think that a bad mood has no significant influence on eating.

\section{Conclusions}

In the course of our research, we studied children's nutrition characteristics with the help of the DEBQ method. Our central objective was to confirm the usability of the scale adapted to children, as well as to point out that parents assess their children's nutrition characteristics in a different way than children themselves. Overall, we managed to achieve both aims. There was a significant difference in all three studied dimensions in the assessment of the parents and their children. The most significant difference was in terms of external eating, which suggests that the parents overestimate their children's self-control, they believe that they are less enticed by delicious food. In parallel, the parents overestimate their children's nutrition characteristics regarding restrained eating factors, i.e. they think their children are characterised by higher self-restraint. This result can be drawn in parallel with Hong 
et al. (2019) findings that $48.5 \%$ of the surveyed parents underestimated their child's weight, which may lead them to judge their eating behavior more positively than real. In terms of emotional eating, both the children and their parents were dismissive, i.e. they believe that the children are not likely to eat because of sadness.

Self-control is an important factor in rejecting unhealthy nutrition and choosing a healthier lifestyle. Therefore, our results raise awareness because parents seem to (falsely) overestimate their children's self-restraining ability in terms of nutrition, thus we can also assume that they perceive the risk of obesity less dangerous regarding their children. Based on this, it would be sensible to place more emphasis on raising the awareness of parents about reconsidering their position regarding their children's self-control in the communication targeted at children's healthy nutrition.

A limitation of our research was that too many children with normal body weight were included in the sample, and we did not examine other influencing factors such as financial status or parent's eating attitudes. Our future plans include extending the research to more elementary schools and examining the differences between eating behaviors split by BMI category.

\section{Acknowledgments}

The research was funded by the EFOP-3.6.1-16-2016-00008 tender entitled "Developing smart life science technologies, methodologies and applications and creating innovative processes and services built on the knowledge base of Szeged".

\section{References}

Bailly, N. - Maitre, I. - Amanda, M. - Hervé, C. - Alaphilippe, D. (2012): The Dutch Eating Behaviour Questionnaire (DEBQ). Assessment of eating behaviour in an aging French population. Appetite, 59, 3, 853-858. https://doi.org/10.1016/j.appet.2012.08.029

Black, A. - D'Onise - K.m McDermott, R. - Vally, H. - O'Dea, K. (2017): 'How effective are family-based and institutional nutrition interventions in improving children's diet and health? A systematic review. BMC Public Health, $17,1,818$.

Boyland, E. J. - Whalen, R. (2015): Food advertising to children and its effects on diet: review of recent prevalence and impact data. Pediatric Diabetes, 16, 5, 331-337.

Böröndi- Fülőp N. - Szakály Z. (2010): Milyen tényezők befolyásolják a fiatalok táplálkozását? [What factors affect the nutriton of young people?] In $M O K$ XVI. Országos Konferencia Tanulmánykötet - Új marketing világrend. (in Hungarian)

Cebolla, A. - Barrada, J. R. - van Strien, T. - Oliver, E. - Baños, R. (2014): Validation of the Dutch Eating Behavior Questionnaire (DEBQ) in a sample of Spanish women. Appetite, 73, 58-64. https://doi.org/10.1016/j.appet.2013.10.014 
Danielsen, K. K. - Svendsen, M. - Mæhlum, S. - Sundgot-Borgen, J. (2013): Changes in body composition, cardiovascular disease risk factors, and eating behavior after an intensive lifestyle intervention with high volume of physical activity in severely obese subjects: a prospective clinical controlled trial. Journal of obesity, 2013, 325-464. doi: 10.1155/2013/325464

European Food Information Council (2012): Szülői befolyás a gyermekek ételválasztására és energiabevitelére. [Parental influence on children's food choices and energy intake] Food Today 09/2012 (in Hungarian)

Garner, D. M. - Garfinkel, P. E. (1979): The Eating Attitudes Test: an index of the symptoms of anorexianervosa. Psychological Medicine, 9, 273-279.

Heaven, P. C. - Mulligan, K. - Merrilees, R. - Woods, T. - Fairooz, Y. (2001): Neuroticism and conscientiousness as predictors of emotional, external, and restrained eating behaviors. The International Journal of Eating Disorders, 30, 2, 161-166. o.

Herman, C. P. - Polivy, J. (1980): Restrained eating. In Stunkard, A. J. (szerk.): Obesity. Saunders, Philadelphia, 208-225.

Herman, C. P. - Polivy, J. (1975): Anxiety, restraint, and eating behavior. Journal of abnormal psychology, 84, 6, 666.

Hong, S. A. - Peltzer, K. - Jalayondeja, C. (2019): Parental misperception of child's weight and related factors within family norms. Eating and weight disorders: EWD, 24, 3, 557-564.

Huszka, P. - Dernóczy-Polyák, A. (2015): Táplálékod legyen egészséged élelmiszer fogyasztási szokások vizsgálata a fiatalok körében. [Your diet should be your health - studying food consumption habits among young people] In EMOK - XXI. Országos Konferencia Tanulmánykötet-Marketing hálózaton innen és túl. (in Hungarian)

Kaplan, H. I. - Kaplan, H. S. (1957): The psychosomatic concept of obesity. Journal of Nervous and Mental Disease, 125, 181-201.

Kásler, T. (2017): Application of the Child Eating Behavior Questionnaire in Hungary In Tükrözödés, Társtudományok, Trendek, Fogyasztás EMOK XXIII. országos konferencia tanulmánykötet.

Khatoon, S. - Ahmed, A. - Zubair, M. (2017): BMI; Dietary Practics Of School Going Children And Their BMI May Predict Future Health Hazards. Professional Medical Journal, 24, 9, 1392-1397.

Lipták L. - Huszár S. - Buzás N. (2018): Evési magatartás vizsgálata fiatal felnőttek körében - különös tekintettel az eltérő testsúllyal rendelkező fogyasztói csoportokra. In Józsa, L. - Korcsmáros, E. - Seres Huszárik, E. (szerk.): A hatékony marketing - EMOK 2018 Nemzetközi Tudományos Konferencia konferenciakötete. Selye János Egyetem, Komárom. ISBN: 978-80-8122-2, 781-792.

Moreira, G. S. X. - Mota, D. C. L. - Lorenzato, L. - Kakeshita, I. S. - Costa, T. M. B. - Almeida, S. S. (2017): Transcultural Adaptation Procedures for the Dutch Eating Behavior Questionnaire (DEBQ) for Brazil. Avaliçãao Psicológica, 16, 4, 426-435. 
Schachter, S. - Rodin, J. (1974): Obese humans and rats. Lawrence Erlbaum, Washington, D.C.

Statisztikai tükör, KSH (2017): Az egészségügyi kiadások alakulása Magyarországon 2010-2015 [Health Expenditure in Hungary 2010-2015] (in Hungarian)

Stunkard, A. J. - Messick, S. (1985): The three-factor eating questionnaire to measure dietary restraint, disinhibition and hunger. Journal of Psychosomatic Research, 29, 1, 71-83.

Kiss, V. - Szakály, Z. (2016): A szülők hatása a középiskolás diákok egészségtudatos táplálkozására. [The influence of parents on the health conscious nutrition of high school students.] In EMOK - XXII. Országos Konferencia-Hitelesség és értékorientáció a marketingben (in Hungarian)

Van Strien, T. - Frijters, J. E. R. - Bergers, G. P. A. - Defares, P. B. (1986): The Dutch Eating Behavior Questionnaire (DEBQ) for Assessment of Restrained, Emotional, and External Eating Behavior. International Journal of Eating Disorders, 5, 2, 295-315.

Van Strien, T. - Oosterveld, P. (2008): The children's DEBQ for assessment of restrained, emotional, and external eating in 7- to 12-year-old children. International Journal of Eating Disorders, 41, 1, 72-81. https://doi.org/10.1002/eat.20424

Vázquez, F. - Torres-Iglesias, A. (2012): Behavioral and Psychosocial Factors in Childhood Obesity. Childhood Obesity.

Varga-Hatos K. - Karner, C. (2008): A lakosság egészségügyi állapotát befolyásoló tényezök. [Factors affecting the health of the population] Egészségügyi gazdasági szemle, 46, 2, 25-33. (in Hungarian)

Wu, S. - Cai, T. - Luo, X. (2017): Validation of the Dutch Eating Behavior Questionnaire (DEBQ) in a sample of Chinese adolescents. Psychology, Health \& Medicine, 22, 3, 282-288. 